\title{
Structural and Functional Characterization of the Alanine Racemase from
}

\section{Streptomyces coelicolor A3(2)}

Raffaella Tassoni ${ }^{1^{*}}$, van der Aart, L.T. ${ }^{2^{*}}$, Ubbink, M. ${ }^{1}$, Van Wezel, G. P. ${ }^{2}$, Pannu, N. S. ${ }^{1 \#}$

5

1 Leiden Institute of Chemistry, Leiden University, Gorlaeus Laboratories, Eisteinweg 55, 2333 CC Leiden, The Netherlands

2 Microbial Biotechnology and Health, Institute of Biology Leiden, Leiden University, Sylviusweg 72, 2333 BE Leiden, The Netherlands

* These authors contributed equally to the work

\# Corresponding authors:

Navraj S. Pannu: raj@chem.leidenuniv.nl

Gilles P. van Wezel: g.wezel@biology.leidenuniv.nl

Marcellus Ubbink: m.ubbink@chem.leidenuniv.nl 


\section{Abstract}

The conversion of L-alanine (L-Ala) into D-alanine (D-Ala) in bacteria is performed by pyridoxal phosphate-dependent enzymes called alanine racemases. D-Ala is an essential component of the bacterial peptidoglycan and hence required for survival. The Gram-positive bacterium Streptomyces coelicolor has at least one alanine racemase encoded by alr. Here, we describe an alr deletion mutant of $S$. coelicolor which depends on D-Ala for growth and shows increased sensitivity to the antibiotic D-cycloserine (DCS). The crystal structure of the alanine racemase (Alr) was solved with and without the inhibitors DCS or propionate. The crystal structures revealed that Alr is a homodimer with residues from both monomers contributing to the active site. The dimeric state of the enzyme in solution was confirmed by gel filtration chromatography, with and without L-Ala or D-cycloserine. Specificity of the enzyme was $66+/-3 U \mathrm{mg}^{-1}$ for the racemization of L- to D-Ala, and $104+/-7 \mathrm{U} \mathrm{mg}^{-1}$ for the opposite direction. Comparison of Alr from S. coelicolor with orthologous enzymes from other bacteria, including the closely related D-cycloserine-resistant Alr from S. lavendulae, strongly suggests that structural features such as the hinge angle or the surface area between the monomers do not contribute to D-cycloserine resistance, and the molecular basis for resistance therefore remains elusive.

\section{Keywords}

Alanine racemase; Peptidoglycan; Actinobacteria; Antibiotic resistance; X-ray crystallography 


\section{INTRODUCTION}

All canonical, proteinogenic amino acids, with the exception of glycine, have a stereocenter at the $\mathrm{C} \alpha$ and can exist either as the L- or D-enantiomer. While in the past it was generally accepted that only L-amino acids had a role in living organisms, studies revealed a variety of roles for free D-amino acids, for example in the regulation of bacterial spore germination and peptidoglycan structure [1]. Peptidoglycan is essential for cell shape and osmotic regulation and its biosynthesis is dependent on the availability of the less naturally abundant D-alanine [2-4]. D-alanine (D-Ala) is generated through racemization of the abundant L-enantiomer (LAla) by the enzyme alanine racemase [5].

Alanine racemases (Alr; E.C. 5.1.1.1) are conserved bacterial enzymes that belong to the Fold Type III of pyridoxal phosphate (PLP)-dependent enzymes. Crystallographic studies of Alr's from different bacterial species revealed a shared, conserved fold consisting of an eightstranded $\alpha / \beta$ barrel at the $N$-terminal domain and a second, $C$-terminal domain mainly consisting of $\beta$-sheets. The PLP cofactor is bound to a very conserved lysine residue at the $\mathrm{N}$-terminal side of the last helix of the barrel. In all studies, Alr's crystals consist of homodimers, with residues from both monomers participating in the formation of the active site. Nevertheless, in-solution studies indicated an equilibrium between monomeric and homodimeric states in solution, with the homo-dimer being the catalytically active form $[6,7]$.

Streptomyces coelicolor is the most widely studied member of the Streptomycetes, which are Gram-positive bacteria with a multicellular mycelial life style that reproduce via sporulation [8]. They are of great importance for medicine and biotechnology, accounting for over half of all antibiotics, as well as for many anticancer agents and immunosuppressants available on the market $[9,10]$. Here we describe the heterologous expression, purification and crystal structure of S. coelicolor Alr, encoded by alr (SCO4745). An alr null mutant of $S$. coelicolor depends on exogenous D-Ala for growth. The purified enzyme catalyzed the racemization of L-Ala to D-Ala in vitro and was shown to be a dimer from gel filtration, both in the absence and presence of L-Ala or the inhibitor D-cycloserine (DCS). Furthermore, the crystal structure of the enzyme has been solved both in the absence and in the presence of the inhibitors 
bioRxiv preprint first posted online Nov. 26, 2016; doi: http://dx.doi.org/10.1101/089938. The copyright holder for this preprint

(which was not peer-reviewed) is the author/funder, who has granted bioRxiv a license to display the preprint in perpetuity.

All rights reserved. No reuse allowed without permission.

DCS and propionate. The comparison of the Alr enzymes from S. coelicolor and its close relative the DCS-resistant Streptomyces lavendulae [11] questions the structural role of Alr in DCS resistance.

\section{MATERIALS AND METHODS}

\section{Bacterial strains and culturing conditions}

Escherichia coli strains JM109 [12] and ET12567 [13] were used for routine cloning procedures and for extracting non-methylated DNA, respectively. E. coli BL21 Star (DE3)pLysS was used for protein production. Cells of E. coli were incubated in lysogenic broth (LB) at $37^{\circ} \mathrm{C}$. Streptomyces coelicolor A3(2) M145 was obtaime from the John Innes cenre strin collection and was the parent of all mutants in this work. All media and routine Streptomyces techniques have been described in the Streptomyces laboratory manual [13]. Soy, flour and mannitol (SFM) agar plates were used for propagating $S$. coelicolor strains and for preparing spore suspensions. Solid minimal medium (MM) agar plates supplied with $1 \%(\mathrm{w} / \mathrm{v})$ mannitol was used for phenotypic characterization. The MIC for D-cycloserine was measured in triplicate in 96 well plates containing solid MM, D-alanine and D-cycloserine. Growth was assayed after two days using a resazurin-assay [14].

\section{Streptomyces coelicolor knock-out mutant and genetic complementation}

S. coelicolor alr deletion mutants were constructed as previously described [15]. The -1238/3 and $+1167 /+2378$ regions relative to the start of alr were amplified by PCR using primer alr_LF and alr_LR, and alr_RF and alr_RR (Table S2) as described [16]. The left and right flanks were cloned into the unstable, multi-copy vector pWHM3 (Table S1) [17], to allow for efficient gene disruption [18]. The apramycin resistance cassette aac(3)IV flanked by loxP sites was cloned into the engineered Xbal site to create knock-out construct pGWS1151. Media were supplemented with $1 \mathrm{mM}$ D-Ala to allow growth of alr mutants. The correct recombination event in the mutant was confirmed by PCR. For genetic complementation, the $-575 /+1197$ region (numbering relative to the alr translational start codon) encompassing the 
bioRxiv preprint first posted online Nov. 26, 2016; doi: http://dx.doi.org/10.1101/089938. The copyright holder for this preprint

(which was not peer-reviewed) is the author/funder, who has granted bioRxiv a license to display the preprint in perpetuity.

All rights reserved. No reuse allowed without permission.

promoter and coding region of SCO4745 was amplified from the S. coelicolor M145 chromosome using primer 4745FW-575 and 4745RV+1197 (Table S2) and cloned into pHJL401 [19]. pHJL401 is a low-copy number shuttle vector that is very well suited for genetic complementation experiments [20].

\section{Cloning, protein expression and purification}

The alr gene (SCO4745) was PCR-amplified from genomic DNA of Streptomyces coelicolor using primers alr-FW and alr-RV (Table S2), and cloned into pET-15b with a $\mathrm{N}$-terminal $\mathrm{His}_{6}$ tag. The construct was transformed into E. coli BL21 Star (DE3)pLysS electrocompetent cells (Novagen). E. coli cultures were incubated in LB medium at $37^{\circ} \mathrm{C}$ until an $\mathrm{OD}_{600}$ of 0.6 and gene expression induced by adding $0.5 \mathrm{mM}$ isopropyl $\beta$-D-1-thiogalactopyranoside (IPTG) followed by overnight incubation at $16^{\circ} \mathrm{C}$. $\mathrm{His}_{6}$-tagged Alr was purified using a pre-packed HisTrap FF column (GE Healthcare) as described [21]. Briefly, after binding of the protein, the column was washed with ten column volumes of $20 \mathrm{mM}$ sodium phosphate buffer, $\mathrm{pH}$ 7.0, $500 \mathrm{mM} \mathrm{NaCl}$ and $50 \mathrm{mM}$ imidazole and $\mathrm{N}$-terminally $\mathrm{His}_{6}$-tagged Alr eluted with the same buffer but containing $250 \mathrm{mM}$ imidazole. Fractions containing the Alr were deslated using a PD-10 column (GE Healthcare) to remove the imidazole and Alr purified further by gel-filtration using a Superose-12 column (GE Healthcare). The collected fractions were analyzed by SDS-PAGE and those containing pure Alr were pooled, concentrated using a Centriprep centrifugal filter unit (10 kDa cut-off, Millipore), and flash-frozen in liquid nitrogen.

\section{Enzymatic assay for recombinant Alr}

$0.2 \mathrm{nM}$ purified Alr was added to $10 \mathrm{mM}$ L-Ala in $20 \mathrm{mM}$ PBS buffer, $\mathrm{pH} 7.0$ and incubated at room temperature $\left(21^{\circ} \mathrm{C}\right)$ for $0,1,5,15,30$, and $60 \mathrm{~min}$. The reaction was stopped by heat inactivation for $3 \mathrm{~min}$ at $95^{\circ} \mathrm{C}$. As a control, $0.2 \mathrm{nM}$ heat-inactivated Alr was used. A 20- $\mu \mathrm{L}$ aliquot of the reaction mixture was added to a 2-mL well in a 24-well plate containing solid $\mathrm{MM}$, inoculated with the alr mutant. 0, $10 \mu \mathrm{M}, 50 \mu \mathrm{M} 100 \mu \mathrm{M}, 500 \mu \mathrm{M}$ and $1 \mathrm{mM}$ D- and L-Ala were added as controls. 


\section{Mass spectrometry analysis}

125 The identity of the heterologous Alr was verified by mass spectrometry of the tryptic digest. Five $\mu \mathrm{g}$ of purified Alr were denatured in $50 \mu \mathrm{L} 8 \mathrm{M}$ urea in $100 \mathrm{mM} \mathrm{NH}_{4} \mathrm{HCO}_{3}$. The cysteine residues were reduced with $5 \mu \mathrm{L}$ of $5 \mathrm{mM}$ dithiothreitol (DTT) for $15 \mathrm{~min}$ at $50^{\circ} \mathrm{C}$ alkylated with $10 \mu \mathrm{L}$ of $10 \mathrm{mM}$ iodoacetamide at room temperature in the dark for $30 \mathrm{~min}$. The protein was digested overnight at $37^{\circ} \mathrm{C}$ using $50 \mathrm{ng}$ of modified porcine trypsin (Promega) in $350 \mu \mathrm{L}$ of $20 \mathrm{mM} \mathrm{NH} \mathrm{NH}_{4} \mathrm{HCO}_{3}$. The tryptic digest was desalted using stage tips [22], dried and resuspended in $50 \mu \mathrm{L}$ of $\mathrm{H}_{2} \mathrm{O}: \mathrm{ACN}: \mathrm{FA}$ (96.9:3:0.1) solution. The LTQ-Orbitrap (Thermo Fisher Scientific, Waltham, MA) tandem mass spectrometry analysis was performed as previously described [22].

\section{Crystallization conditions and data collection}

Purified Alr was concentrated to $20 \mathrm{mg} \mathrm{mL}^{-1}$ and crystallization conditions were screened by sitting-drop vapor-diffusion using the JCSG+ and PACT premier (Molecular Dimensions) screens at $20^{\circ} \mathrm{C}$ with $500-\mathrm{nL}$ drops. The reservoir $(75 \mu \mathrm{L})$ was pipetted by a Genesis $\mathrm{RS} 200$ robot (Tecan). Drops were made by an Oryx6 robot (Douglas Instruments). After 1 day, crystals grew in condition number 2-38 of PACT premier, which consisted of $0.1 \mathrm{M}$ BIS-TRIS propane, pH 8.5, $0.2 \mathrm{M} \mathrm{NaBr}, 20 \%$ (w/v) PEG3350. Bigger crystals were grown in 1- $\mu \mathrm{L}$ drops. Prior to flash-cooling in liquid nitrogen, crystals were soaked in a cryosolution consisting of mother liquor, $10 \%$ glycerol and 10,5 , or $1 \mathrm{mM}$ inhibitor to obtain the DCS- and propionate-bound structures.

X-ray data collection was performed at the ESRF (Grenoble, France) on beamline ID23-1 [23] using a PIXEL, Pilatus_6M_F X-ray detector. A total of 1127 frames were collected for the native Alr, with an oscillation of $0.15^{\circ}$, an exposure time of $0.378 \mathrm{~s}$, total $426.006 \mathrm{~s}$. The data set was processed by XDS [23] and scaled by AIMLESS [24] to a resolution of $2.8 \AA$. For the DCS-bound Alr 960 frames were collected, with an oscillation range of $0.15^{\circ}$, an 

structure, 1240 images were collected, with an oscillation degree of $0.1^{\circ}$, an exposure time per image of $0.037 \mathrm{~s}$, and a total time of $45.88 \mathrm{~s}$. Both inhibitor-bound data sets were autoprocessed by the EDNA Autoprocessing package in the mxCuBE [25] to a resolution of $1.64 \AA$ and $1.51 \AA$ for the DCS-bound and propionate-bound Alr, respectively. The structures were solved by molecular replacement with MOLREP [26] using 1VFH as a search model from the CCP4 suite [27] and iteratively refined with REFMAC [28]. Manual model building was done using Coot [29].

\section{Enzyme kinetics}

The racemization activity of Alr was determined by quantifying the derivatization product of Land D-Ala by HPLC, as previously described [30, 31]. The derivatization reagent consisted of a methanol solution of $10 \mathrm{mg} \mathrm{mL}^{-1}$ o-phthalaldehyde (OPA, Sigma-Aldrich) and $10 \mathrm{mg} \mathrm{mL}^{-1}$ Boc-L-Cys (Sigma-Aldrich). A $0.4 \mathrm{M}$ boric acid solution was adjusted to $\mathrm{pH} 9.0$ with sodium hydroxide. The reaction mixture consisted of $20 \mu \mathrm{L}$ of $20 \mathrm{mM}$ sodium phosphate buffer, $\mathrm{pH}$ 7.0 containing varying amounts of L- or D-Ala from $281 \mu \mathrm{M}$ to $20 \mathrm{mM}$. The reaction was started by adding $100 \mathrm{nM}$ of enzyme and stopped after $10 \mathrm{~min}$ at $25^{\circ} \mathrm{C}$ by adding $20 \mu \mathrm{L}$ of $2 \mathrm{~N} \mathrm{HCl}$. The reaction mixture was neutralized by $\mathrm{NaOH}$. After adding $350 \mu \mathrm{L}$ of boric acid buffer and $100 \mu \mathrm{L}$ of derivatization reagent, derivatization was conducted for $5 \mathrm{~min}$ at $25^{\circ} \mathrm{C}$. The fluorescent products were separated on a Kinetex EVO C18 column (Phenomenex) by a gradient from $24 \%$ to $46.75 \%$ of acetonitrile in water in 30 min and detected by a Shimadzu RF-10AXL fluorescence detector. 


\section{RESULTS AND DISCUSSION}

\section{Creation of an alr null mutant of $S$. coelicolor}

To study the role of alr in amino acid metabolism and in morphogenesis of $S$. coelicolor, a deletion mutant was created by removal of the entire coding region (see Materials \& Methods). In line with its expected role in biosynthesis of the essential D-amino acid D-Ala, alr null mutants depended on exogenously added D-Ala $(50 \mu \mathrm{M})$ for growth (Fig 1a). Reintroducing a copy of the alr gene via plasmid pGWS1151 complemented the mutant phenotype, allowing growth in the absence of added D-Ala (Fig 1a). These data show that alr encodes alanine racemase in $S$. coelicolor, and that it most likely is the only gene encoding this enzyme.

\section{Alr is the only alanine racemase in S. coelicolor}

The Alr from S. coelicolor (Alr ${ }_{\text {Sco }}$ ) shares $74.9 \%$ aa sequence identity with the Alr from the DCS-producing Streptomyces lavendulae (Alr $\mathrm{Sla})$ [11] and $37.9 \%$ with the well-studied Alr from Geobacillus stearothermophilus ( Alr $\left._{\text {Gst }}\right)$ [32] (Fig. 2). To analyze the activity and kinetics of the enzyme, recombinant $\mathrm{His}_{6}$-tagged Alr was expressed in E. coli BL21 Star cells and purified to homogenity (see Materials and Methods section). Around $45 \mathrm{mg}$ of pure Alr was obtained from $1 \mathrm{~L}$ of bacterial culture and Alr was identified using mass spectrometry (Table S4).

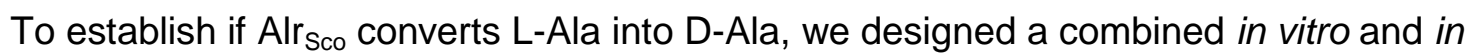
vivo assay, whereby $10 \mathrm{mM}$ L-Ala was incubated with $0.2 \mathrm{nM}$ purified Alr-His ${ }_{6}$ for $10 \mathrm{sec}$ to $60 \mathrm{~min}$, after which the enzyme was heat-inactivated and the mixture was added to minimal media (MM) agar plates, followed by plating of $10^{6}$ spores of the alr null mutant and incubation of 5 days at $30^{\circ} \mathrm{C}$ (Fig. 1b). If Alr converts L-Ala into D-Ala, the reaction should generate sufficient D-Ala to allow restoration of growth to alr null mutants. Indeed, sufficient D-Ala was produced to allow growth of the alr null mutant, whereby biomass accumulaiton was proportional to the incubation time, while a control experiment with extracts from heatinactivated Alr did not give any growth (Fig. 1b). Addition of D-Ala also restored growth of alr 
bioRxiv preprint first posted online Nov. 26, 2016; doi: http://dx.doi.org/10.1101/089938. The copyright holder for this preprint

(which was not peer-reviewed) is the author/funder, who has granted bioRxiv a license to display the preprint in perpetuity.

All rights reserved. No reuse allowed without permission.

mutants, while no growth was seen for cultures grown in the presence of added L-Ala. Taken together, this shows that no Alr activity is present in S. coelicolor alr mutants, and that Alr actively converts L-Ala into D-Ala in vitro.

The kinetic parameters of recombinant Alr $_{\text {Sco }}$ were determined using both L- and DAla as substrates. The enzyme shows a $\mathrm{K}_{\mathrm{m}}$ of $6.3 \mathrm{mM}$ and $8.9 \mathrm{mM}$ towards L- and D-Ala, respectively (Table 1). For comparison, kinetic parameters of Alr $_{\text {Sla }}[11]$ and Alr $_{\text {Gst }}$ are also shown in Table 1.

To analyze possible multimerization of $\mathrm{Alr}_{\mathrm{sco}}$, analytical gel filtration was used, which established an apparent molecular weight for the protein of $83 \mathrm{kDa}$ in solution both in the absence and in the presence of L-Ala and DCS (Figure S2); this corresponds roughly to two Alr proteins (43.4 kDa per subunit). See Supplementary Data for more details. These data suggest that $\mathrm{Alr}_{\mathrm{Sco}}$ forms a dimer in solution, both in the presence and in the absence of ligands.

\section{Overall structure of Alr from Streptomyces coelicolor}

The crystal structure of ligand-free Alr Sco $_{\text {sas }}$ watermined to a resolution of $2.8 \AA$ (Table 2 ). The overall structure is similar to that of other prokaryotic Alr proteins $[11,33]$. The asymmetric unit contains four protein molecules (A-D), which interact in a head-to-tail manner to form two dimers (dimer A-B and C-D, Fig. 3a). Each monomer has two structurally distinct domains. The $\mathrm{N}$-terminal domain, comprising residues $1-259$, has an eight-stranded $\alpha / \beta$-barrel fold, typical of phosphate-binding proteins. The $C$-terminal domain, residues 260 391, contains mostly $\beta$-strands (Fig. 3b). $96 \%$ of the amino acids are in the preferred regions of the Ramachandran plot, $4 \%$ are in the allowed regions and no residues are in the unfavored areas. After refinement, the r.m.s. deviation between Ca's of the two interacting molecules $A$ and $B$ is $0.0794 \AA$, and between $C$ and $D$ is $0.1431 \AA$.

There are two active sites per dimer, which are located at the interface between each $\alpha / \beta$-barrel of one subunit and the $C$-terminal domain of the other. The catalytic core (Fig. $4 \mathrm{a}$ ) consists of the PLP cofactor, a Lys, and a Tyr, which is contributed by the other subunit. The 
PLP is bound through an internal aldimine bond to the amino group of Lys46, located at the $C$-terminal side of the first $\beta$-strand of the $\alpha / \beta$-barrel. The side chain of the catalytic Lys46 points out of the $\alpha / \beta$-barrel, towards the $C$-terminal domain of the interacting subunit, and in particular, towards Tyr283'. The phosphate group of the PLP is stabilized by hydrogen bonds with the side chains of Tyr50, Ser222 and Tyr374, and with the backbone of Gly239, Ser222 and Ile240. The pyridine ring of the PLP is stabilized by a hydrogen bond between the $\mathrm{N}-1$ of the cofactor and $\mathrm{N} \varepsilon$ of Arg237. The C2A of the PLP also interacts with oxygen Q1 of the carboxylated Lys141. All residues stabilizing the PLP cofactor (Tyr50, Ser222, Gly239,

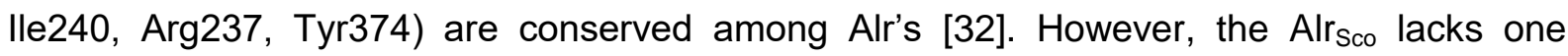
important hydrogen bond between Arg148 and the phenolic oxygen of the PLP molecule, as already observed for the Alr $_{\text {Sla }}$ [34] [35]. Among the residues involved in PLP-stabilization, Tyr374, which corresponds to Tyr354 in the well-studied Alr $r_{\text {Gst }}$, is particularly interesting. In fact, while always regarded as a PLP-stabilizer, Tyr354 was shown to be actually anchored by the hydrogen bond with the PLP so to ensure substrate specificity of the Alr [36].

\section{Alr crystal structures bound to propionate and DCS}

The structure of $\mathrm{Alr}_{\mathrm{Sco}}$ was solved in the presence of the two inhibitors propionate [37] and DCS [11] to a resolution of $1.51 \AA$ and $1.64 \AA$, respectively. In $\mathrm{Alr}_{\mathrm{Sco}}$, the carboxylic group of propionate binds in the same orientation in all four active sites present in the crystal unit. One of the carboxylic oxygens of propionate forms hydrogen bonds with the amino group of Met331', the phenolic oxygen and CE2 of Tyr283' and a water molecule, which bridges the substrate to several other water molecules in the active site. The second carboxylic oxygen of propionate interacts with $\mathrm{N} \zeta$ of Lys46, C4A of PLP, the phenolic oxygen of Tyr283' and a water molecule. The electron density around C3 of propionate shows that this atom can have several orientations in the active site. In fact, it can either interact with $\mathrm{O} 4$ of the phosphate of PLP, the phenolic oxygen of Tyr283' and a water molecule, or with the phenolic oxygen of Tyr50, the CE of Met331', N $\zeta$ of Lys46 and C4A of PLP (Fig. 4b). Both in Alr ${ }_{\text {Sco }}$ and Alr Gst $_{\text {the }}$ the hydrogen-bonding network stabilizing the propionate is very conserved. As argued by [37], 
the propionate-bound form of the Alr can be considered a mimic of the Michaelis complex formed between the enzyme and its natural substrate L-Ala. covalently inhibits Alr [11, 38-42]. The structure of the Alr ${ }_{\text {Sco }}$ in complex with DCS shows that the amino group of the inhibitor replaces the Lys46 in forming a covalent bond with the PLP C4 (Fig. 4c). The nitrogen and oxygen atoms in the isoxazole ring form hydrogen bonds with Tyr302', Met331' and a water molecule. The hydroxyl group of the DCS ring also interacts with Met331' and Arg148 (Fig. 4c). The catalytic Tyr283' is at hydrogen-bond distance from the amino group of DCS. DCS molecules superpose well in three of the active sites of the crystal (A, B and C). However, the DCS-PMP adduct in the fourth site showed a shift of the DCS compared to the other sites, while PLP still superposed well. Comparison of the hydrogen bonds in the proximity of the active site in the free and in the DCS-bound form of Alr, revealed a role for Arg148 in substrate stabilization. In fact, while the side chain of Arg148 is hydrogen-bonded to Gln333 in free Alr, it shifted towards the hydroxyl moiety of the DCS upon binding of the inhibitor. Gln333 was stabilized by interaction with carboxylated Lys141. The rearrangement of the hydrogen bonds involving Arg148, GIn333 and Lys141 does not occur in the propionate-bound structure, suggesting that Arg148 is involved in stabilization of the carboxylic group of the substrate.

\section{Alr and DCS resistance}

$\mathrm{Alr}_{\text {Sco }}$ shows high sequence and structural similarity to Alr $\mathrm{r}_{\text {Sla. }}$ Based on crystallographic studies, Alr sla was proposed as one determinant of DCS resistance in the producer strain [11]. However, detailed structural comparison of different Alr proteins based on interatomic distances between active site residues, dimerization areas and hinge angles (see Supplementary Data), failed to establish a clear correlation between structural features and DCS resistance. It therefore remains unclear what the role of Alr is in DCS resistance in the producer strain. 
bioRxiv preprint first posted online Nov. 26, 2016; doi: http://dx.doi.org/10.1101/089938. The copyright holder for this preprint

(which was not peer-reviewed) is the author/funder, who has granted bioRxiv a license to display the preprint in perpetuity.

All rights reserved. No reuse allowed without permission.

In conclusion, our work shows that SCO4745 encodes the only Alr in S. coelicolor A3(2) and is essential for growth. Our structural studies on $\mathrm{Alr}_{\mathrm{Sco}}$ and comparison to $\mathrm{Alr}_{\text {Sla }}$ suggest that there are more factors contributing to DCS resistance in bacteria, which relates well to recent studies on DCS-producing streptomycetes [43] and DCS-resistant strains of M. tuberculosis [44-47], . The availability of a S. coelicolor alr-null mutant and the crystal structure of the Alr from the same bacterium offer a new, valuable model for the study of DCS resistanc 


\section{REFERENCES}

1. Cava, F., et al., Emerging knowledge of regulatory roles of $d$-amino acids in bacteria. Cellular and Molecular Life Sciences, 2011. 68(5): p. 817-831.

2. Lam, H., et al., D-amino acids govern stationary phase cell wall remodeling in bacteria. Science, 2009. 325(5947): p. 1552-5.

3. Steen, A., et al., Autolysis of Lactococcus lactis is increased upon D-alanine depletion of peptidoglycan and lipoteichoic acids. J Bacteriol, 2005. 187(1): p. 114-24.

4. Vollmer, W., D. Blanot, and M.A. de Pedro, Peptidoglycan structure and architecture. FEMS Microbiol Rev, 2008. 32(2): p. 149-67.

5. Walsh, C.T., Enzymes in the D-alanine branch of bacterial cell wall peptidoglycan assembly. Journal of Biological Chemistry, 1989. 264(5): p. 2393-2396.

6. Ju, J., et al., Correlation between catalytic activity and monomer-dimer equilibrium of bacterial alanine racemases. J Biochem, 2011. 149: p. 83 - 89.

7. Strych, U., et al., Purification and preliminary crystallization of alanine racemase from Streptococcus pneumoniae. BMC Microbiol, 2007. 7: p. 40.

8. Claessen, D., et al., Bacterial solutions to multicellularity: a tale of biofilms, filaments and fruiting bodies. Nat Rev Microbiol, 2014. 12(2): p. 115-24.

9. Barka, E.A., et al., Taxonomy, physiology, and natural products of the Actinobacteria. Microbiol Mol Biol Rev, 2016. 80(1): p. 1-43.

10. Hopwood, D.A., Streptomyces in nature and medicine: the antibiotic makers2007, New York: Oxford University Press.

11. Noda, M., et al., Structural Evidence That Alanine Racemase from a d-Cycloserineproducing Microorganism Exhibits Resistance to Its Own Product. Journal of Biological Chemistry, 2004. 279(44): p. 46153-46161.

12. Sambrook, J., E.F. Fritsch, and T. Maniatis, Molecular cloning: a laboratory manual. 2nd ed1989, Cold Spring harbor, N.Y.: Cold Spring Harbor laboratory press.

13. Kieser, T., et al., Practical Streptomyces genetics2000, Norwich, U.K.: John Innes Foundation.

14. Mann, C. and J. Markham, A new method for determining the minimum inhibitory concentration of essential oils. Journal of Applied Microbiology, 1998. 84(4): p. 538544.

15. Swiatek, M.A., et al., Functional analysis of the $\mathrm{N}$-acetylglucosamine metabolic genes of Streptomyces coelicolor and role in the control of development and antibiotic production. J Bacteriol, 2012. 194(5): p. 1136-1144.

16. Colson, S., et al., Conserved cis-acting elements upstream of genes composing the chitinolytic system of streptomycetes are DasR-responsive elements. J Mol Microbiol Biotechnol, 2007. 12(1-2): p. 60-6. 
17. Vara, J., et al., Cloning of genes governing the deoxysugar portion of the erythromycin biosynthesis pathway in Saccharopolyspora erythraea (Streptomyces erythreus). J Bacteriol, 1989. 171(11): p. 5872-81.

18. van Wezel, G.P., et al., GlcP constitutes the major glucose uptake system of Streptomyces coelicolor A3(2). Mol Microbiol, 2005. 55(2): p. 624-36.

19. Larson, J.L. and C.L. Hershberger, The minimal replicon of a streptomycete plasmid produces an ultrahigh level of plasmid DNA. Plasmid, 1986. 15(3): p. 199-209.

20. van Wezel, G.P., et al., Application of redD, the transcriptional activator gene of the undecylprodigiosin biosynthetic pathway, as a reporter for transcriptional activity in Streptomyces coelicolor A3(2) and Streptomyces lividans. J Mol Microbiol Biotechnol, 2000. 2(4): p. 551-6.

21. Mahr, K., et al., Glucose kinase of Streptomyces coelicolor A3(2): large-scale purification and biochemical analysis. Antonie Van Leeuwenhoek, 2000. 78(3-4): p. 253-61.

22. $\mathrm{Li}, \mathrm{N}$., et al., Relative quantification of proteasome activity by activity-based protein profiling and LC-MS/MS. Nat Protoc, 2013. 8(6): p. 1155-68.

23. Kabsch, W., Xds. Acta Crystallogr D Biol Crystallogr, 2010. 66(Pt 2): p. 125-32.

24. Evans, P.R. and G.N. Murshudov, How good are my data and what is the resolution? Acta Crystallogr D Biol Crystallogr, 2013. 69(Pt 7): p. 1204-14.

25. Gabadinho, J., et al., MxCuBE: a synchrotron beamline control environment customized for macromolecular crystallography experiments. J Synchrotron Radiat, 2010. 17(5): p. 700-7.

26. Vagin, A. and A. Teplyakov, MOLREP: an Automated Program for Molecular Replacement. Journal of Applied Crystallography, 1997. 30(6): p. 1022-1025.

27. Winn, M.D., et al., Overview of the CCP4 suite and current developments. Acta Crystallographica Section D: Biological Crystallography, 2011. 67(Pt 4): p. 235-242.

28. Murshudov, G.N., et al., REFMAC5 for the refinement of macromolecular crystal structures. Acta Crystallogr D Biol Crystallogr, 2011. 67(Pt 4): p. 355-67.

29. Emsley, P. and K. Cowtan, Coot: model-building tools for molecular graphics. Acta Crystallographica Section D, 2004. 60(12 Part 1): p. 2126-2132.

30. Hashimoto, A., et al., Determination of free amino acid enantiomers in rat brain and serum by high-performance liquid chromatography after derivatization with $\mathrm{N}$-tert.butyloxycarbonyl-I-cysteine and o-phthaldialdehyde. Journal of Chromatography B: Biomedical Sciences and Applications, 1992. 582(1-2): p. 41-48.

31. Ju, J., et al., Cloning of alanine racemase genes from Pseudomonas fluorescens strains and oligomerization states of gene products expressed in Escherichia coli. Journal of Bioscience and Bioengineering, 2005. 100(4): p. 409-417. 
32. Shaw, J., G. Petsko, and D. Ringe, Determination of the structure of alanine racemase from Bacillus stearothermophilus at 1.9-A resolution. Biochemistry, 1997. 36: p. 1329 - 1342.

33. Shaw, J.P., G.A. Petsko, and D. Ringe, Determination of the Structure of Alanine Racemase from Bacillus stearothermophilus at 1.9- $\AA$ Resolution. Biochemistry, 1997. 36(6): p. 1329-1342.

34. Noda, M., et al., Self-protection mechanism in D-cycloserine-producing Streptomyces lavendulae. Gene cloning, characterization, and kinetics of its alanine racemase and $D$-alanyl-D-alanine ligase, which are target enzymes of D-cycloserine. J Biol Chem, 2004. 279(44): p. 46143-52.

35. Noda, M., et al., Structural evidence that alanine racemase from a D-cycloserineproducing microorganism exhibits resistance to its own product. J Biol Chem, 2004. 279(44): p. 46153-61.

36. Patrick, W., J. Weisner, and J. Blackburn, Site-directed mutagenesis of Tyr354 in Geobacillus stearothermophilus alanine racemase identifies a role in controlling substrate specificity and a possible role in the evolution of antibiotic resistance. Chembiochem, 2002. 3: p. 789 - 792.

37. Morollo, A., G. Petsko, and D. Ringe, Structure of a Michaelis complex analogue: propionate binds in the substrate carboxylate site of alanine racemase. Biochemistry, 1999. 38: p. 3293 - 3301.

38. Fenn, T.D., et al., A Side Reaction of Alanine Racemase: Transamination of Cycloserinet,‡. Biochemistry, 2003. 42(19): p. 5775-5783.

39. Asojo, O.A., et al., Structural and biochemical analyses of alanine racemase from the multidrug-resistant Clostridium difficile strain 630. Acta Crystallographica Section D: Biological Crystallography, 2014. 70(Pt 7): p. 1922-1933.

40. Priyadarshi, A., et al., Structural insights into the alanine racemase from Enterococcus faecalis. Biochim Biophys Acta, 2009. 1794: p. 1030 - 1040.

41. Wu, D., et al., Residues Asp164 and Glu165 at the substrate entryway function potently in substrate orientation of alanine racemase from E. coli: Enzymatic characterization with crystal structure analysis. Protein Sci, 2008. 17: p. 1066 - 1076.

42. Lambert, M.P. and F.C. Neuhaus, Mechanism of d-Cycloserine Action: Alanine Racemase from Escherichia coli W. Journal of Bacteriology, 1972. 110(3): p. 978987.

43. Matsuo, H., et al., Molecular cloning of a D-cycloserine resistance gene from $D$ cycloserine-producing Streptomyces garyphalus. J Antibiot (Tokyo), 2003. 56(9): p. 762-7. 
44. Desjardins, C.A., et al., Genomic and functional analyses of Mycobacterium tuberculosis strains implicate ald in D-cycloserine resistance. Nat Genet, 2016. 48(5): p. 544-51.

45. Hong, W., L. Chen, and J. Xie, Molecular basis underlying Mycobacterium tuberculosis D-cycloserine resistance. Is there a role for ubiquinone and menaquinone metabolic pathways? Expert Opin Ther Targets, 2014. 18(6): p. 691701.

46. Feng, Z. and R.G. Barletta, Roles of Mycobacterium smegmatis D-alanine:D-alanine ligase and $D$-alanine racemase in the mechanisms of action of and resistance to the peptidoglycan inhibitor D-cycloserine. Antimicrob Agents Chemother, 2003. 47(1): p. 283-91.

47. Chen, J.M., et al., A point mutation in cycA partially contributes to the $D$-cycloserine resistance trait of Mycobacterium bovis BCG vaccine strains. PLoS One, 2012. 7(8): p. e43467.

48. Noda, M., et al., A novel assay method for an amino acid racemase reaction based on circular dichroism. Biochem J, 2005. 389: p. 491 - 496.

49. Kato, S., H. Hemmi, and T. Yoshimura, Lysine racemase from a lactic acid bacterium, Oenococcus oeni: structural basis of substrate specificity. Journal of Biochemistry, 2012. 152(6): p. 505-508.

50. Inagaki, K., et al., Thermostable alanine racemase from Bacillus stearothermophilus: molecular cloning of the gene, enzyme purification, and characterization. Biochemistry, 1986. 25: p. 3268 - 3274. 
Table 1. Kinetic parameters for the racemization of L- and D-Ala by the recombinant Alr.

The Michaelis-Menten constant $\left(\mathrm{K}_{\mathrm{m}}\right)$, maximum reaction rate $\left(\mathrm{V}_{\max }\right)$ and catalytic constant $\left(\mathrm{k}_{\text {cat }}\right)$ of the Alr from S. coelicolor $\left(\mathrm{Alr}_{\mathrm{Sco}}\right)$ are compared to the reported $\mathrm{K}_{\mathrm{m}}, \mathrm{V}_{\mathrm{max}}$ and $\mathrm{k}_{\text {cat }}$ of the Alr's from S. lavendulae ( $\left.\operatorname{Alr}_{\mathrm{Sla}}\right)$ and G. stearothermophilus ( $\left.\mathrm{Alr}_{\mathrm{Gst}}\right)$.

\begin{tabular}{|c|c|c|c|c|c|c|}
\hline & \multicolumn{3}{|c|}{$\mathrm{L} \rightarrow \mathrm{D}$} & \multicolumn{3}{c|}{$\mathrm{D} \rightarrow \mathrm{L}$} \\
\hline & $\mathrm{K}_{\mathrm{m}}(\mathrm{mM})$ & $\mathrm{V}_{\max }\left(\mathrm{U} \mathrm{mg}^{-1}\right)$ & $\mathrm{k}_{\text {cat }}\left(\mathrm{s}^{-1}\right)$ & $\mathrm{K}_{\mathrm{m}}(\mathrm{mM})$ & $\mathrm{V}_{\max }\left(\mathrm{U} \mathrm{mg}^{-1}\right)$ & $\mathrm{k}_{\text {cat }}\left(\mathrm{s}^{-1}\right)$ \\
\hline Alr $_{\mathrm{Sco}}$ & $6.3 \pm 0.1$ & $66.3 \pm 3.3$ & $47.9 \pm 2.4$ & $8.9 \pm 0.3$ & $104.1 \pm 7.8$ & $75.2 \pm 5.4$ \\
\hline Alr $_{\text {Sla }}^{\ddagger}$ & $0.4 \pm 0.1$ & $78.6 \pm 4.8^{\ddagger \ddagger}$ & $55 \pm 3.3$ & $0.4 \pm 0.2$ & $90.5 \pm 9.5^{\ddagger \ddagger}$ & $63.3 \pm 6.7$ \\
\hline Alr $_{\text {Gst }}$ & $5.1 \pm 0.6^{*}$ & $2550^{* *}$ & $1533.3 \pm 50^{*}$ & $2.8 \pm 0.4^{*}$ & $1400^{* *}$ & $1016.7 \pm 33^{*}$ \\
\hline
\end{tabular}

${ }^{\ddagger}$ Reactions performed at $37^{\circ} \mathrm{C}[48] ;{ }^{\ddagger \ddagger}$ Calculated using the published data by [49], and a $\mathrm{M}_{\mathrm{W}}=42 \mathrm{kDa} ;{ }^{*}[49] ;{ }^{* *}[50]$. 
Table 2. Data-collection and refinement statistics

\begin{tabular}{|c|c|c|c|}
\hline & Free Alr & DCS-bound Alr & Propionate-bound Alr \\
\hline Space group & P 1211 & P 1211 & P 1211 \\
\hline $\begin{array}{l}\text { Unit-cell parameters } \\
a, b, c, \alpha, \beta, y\end{array}$ & $\begin{array}{l}78.96,87.17,109.63 \\
90.00,102.26,90.00\end{array}$ & $\begin{array}{l}79.74,88.71,109.14 \\
90.00,102.25,90.00\end{array}$ & $\begin{array}{l}79.95,88.58,108.88 \\
90.00,102.60,90.00\end{array}$ \\
\hline $\begin{array}{l}\text { Number of } \\
\text { observations }\end{array}$ & 116287 & 480032 & 532661 \\
\hline $\begin{array}{l}\text { Number of unique } \\
\text { reflections }\end{array}$ & 34569 & 177142 & 224510 \\
\hline Completeness (\%) & 96.0 & 77.3 & 96.6 \\
\hline $\begin{array}{l}\mathrm{R}_{\text {pim }}(\%), \quad \mathrm{CC}(1 / 2) \\
\text { highest resolution bin }\end{array}$ & $0.050,0.991$ & $0.037,0.997$ & $0.071,0.985$ \\
\hline$\langle\mathrm{I} / \sigma(\mathrm{I})\rangle$ & 1.72 & 1.38 & 1.28 \\
\hline Multiplicity & 3.4 & 2.7 & 2.4 \\
\hline Resolution range $(\AA)$ & $107.12,47.78-2.8$ & $\begin{array}{l}\text { 106.60(depositor), } \\
\text { 49.14(EDS)-1.64 }\end{array}$ & $106.26,48.06-1.51$ \\
\hline $\mathrm{R}$ factor $(\%)$ & 21.3 & 21.6 & 21.2 \\
\hline $\mathrm{R}_{\text {free }}(\%)$ & 26.2 & 24.5 & 23.7 \\
\hline \multicolumn{4}{|l|}{ R.m.s. deviations } \\
\hline Bond lengths $(\AA)$ & 0.62 & 0.88 & 0.98 \\
\hline Bond angles $\left({ }^{\circ}\right)$ & 0.84 & 0.96 & 1.05 \\
\hline \multicolumn{4}{|l|}{ Number of atoms } \\
\hline $\begin{array}{l}\text { Protein (Chains A, B, } \\
\text { C, D) }\end{array}$ & $\begin{array}{l}2857,2833,2838, \\
2833\end{array}$ & $\begin{array}{l}\text { 2922, 2851, } 2846, \\
2843\end{array}$ & $\begin{array}{l}3047,2911,2909, \\
2926\end{array}$ \\
\hline PLP & 15 & 22 & 15 \\
\hline Water & 171 & 760 & 804 \\
\hline Ramachandran plot & & & \\
\hline
\end{tabular}


bioRxiv preprint first posted online Nov. 26, 2016; doi: http://dx.doi.org/10.1101/089938. The copyright holder for this preprint (which was not peer-reviewed) is the author/funder, who has granted bioRxiv a license to display the preprint in perpetuity.

All rights reserved. No reuse allowed without permission.

\begin{tabular}{|l|l|l|l|}
\hline$(\%)$ & & & \\
\hline Preferred regions & 96 & 97 & 97 \\
\hline Allowed regions & 4 & 3 & 3 \\
\hline Outliers & 0 & 0 & 0 \\
\hline
\end{tabular}




\section{FIGURE LEGENDS}

\section{Figure 1. SCO4547 encodes alanine racemase Alr.}

(A) The alr null mutant of $S$. coelicolor requires supplemented D-Ala for growth. This phenotype is rescued by the introduction of plasmid pGWS1151, which expresses Alr. Strains were grown for 5 days on SFM agar plates. (B) Rescue of the $S$. coelicolor alr null mutant with D-Ala produced in vitro by Alr. Alr (0.2 nM) was incubated with $10 \mathrm{mM} \mathrm{L-Ala} \mathrm{for}$ $10 \mathrm{sec}$ or $1,5,15,30$ or $60 \mathrm{~min}$, followed by heat inactivation. The reaction mixture was then added to MM agar in 24-well plates and growth of the alr null mutant assessed. As a control, the same experiment was done with heat inactivated Alr $\left(\right.$ Alr $\left.^{\star}\right)$. Note the restoration of growth to the alr mutant after addition of the reaction mixture with active Alr, but not with heatinactivated Alr. The bottom rows show control experiments with added D-Ala or L-Ala (ranging between $0-1 \mathrm{mM}$ ).

Figure 2. Multiple aminoacid sequence alignment of the Alr's from $S$. coelicolor (Sco), $S$. lavendulae (Sla; PDB 1VFT) and G. stearothermophilus (Gst; PDB 1XQK). The sequence alignment showing structural elements of Alr $_{\text {Sco }}$ was generated with ESPript3.0. $\alpha$-helices are shown as large coils labeled $\alpha, 3_{10}$-helices are shown as small coils labeled $\eta, \beta$-strands are shown as arrows labeled $\beta$ and $\beta$-turns are labeled TT. Identical residues are shown on a red background, conserved residues are shown in red and conserved regions are shown in boxes.

Figure 3. Ribbon representation of the Alr from S. coelicolor. (A) The asymmetric unit contains two homo-dimers. The two chains within one dimer are colored in gold and dark cyan. (B) The $N$-terminal domain (1-259) is a $\alpha / \beta$-barrel. The $C$-terminal domain (260-391) mostly comprises $\beta$-strands. The catalytic Tyr283 is highlighted in red. 
Figure 4. Active site of the Alr without ligands (A) and in complex with propionate (B) and Dcycloserine $(\mathrm{C})$. The electron density $2 \mathrm{~F}_{0}-\mathrm{F}_{\mathrm{c}}$ map is shown for the PLP and the two inhibitors. The residues in the active site which are contributed from the monomer not bound to the PLP are indicated as primed numbers. Dotted lines indicate interatomic distances shorter than $3 \AA$. 
Figure 1

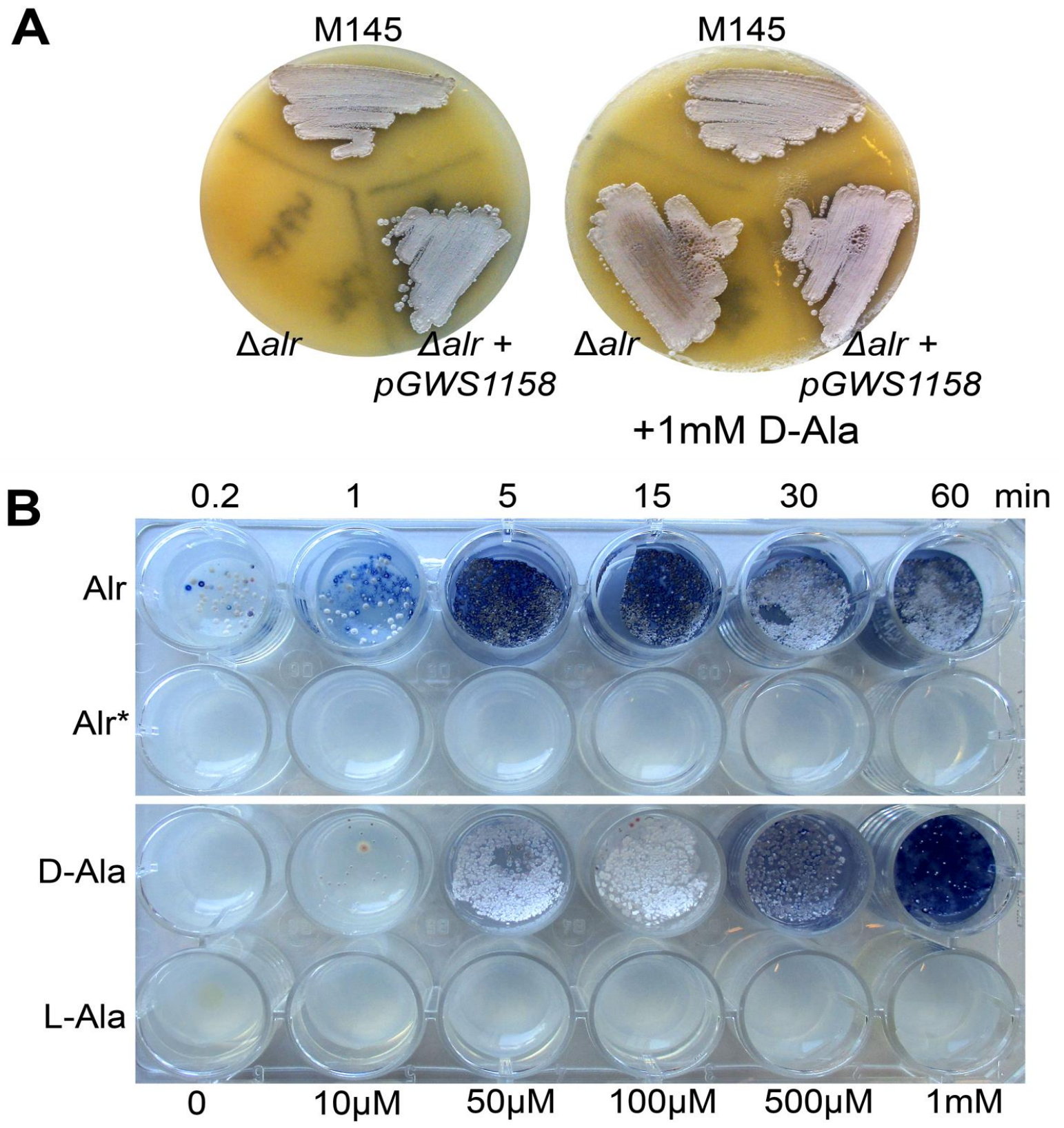




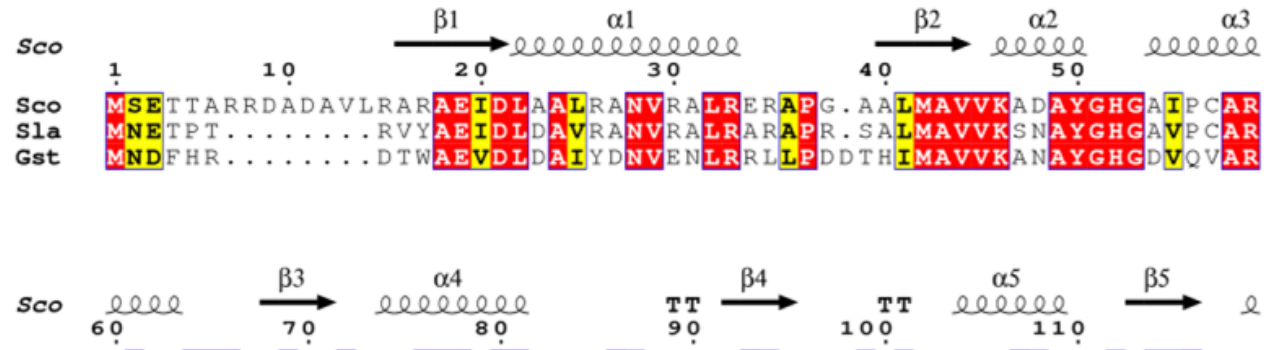

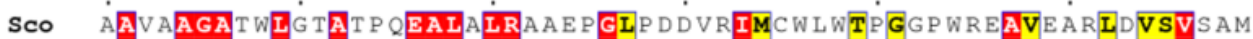
SIa AAQEAGA WLGTATPEEALELRAA. . GIQ. GRIMCWLWTPGGPWREAIETDIDVSVSGM Gst TALEAGASRAVAFLDEALALRE. GIE. A A ILVLG SRPADAALAAQRIALVFRS
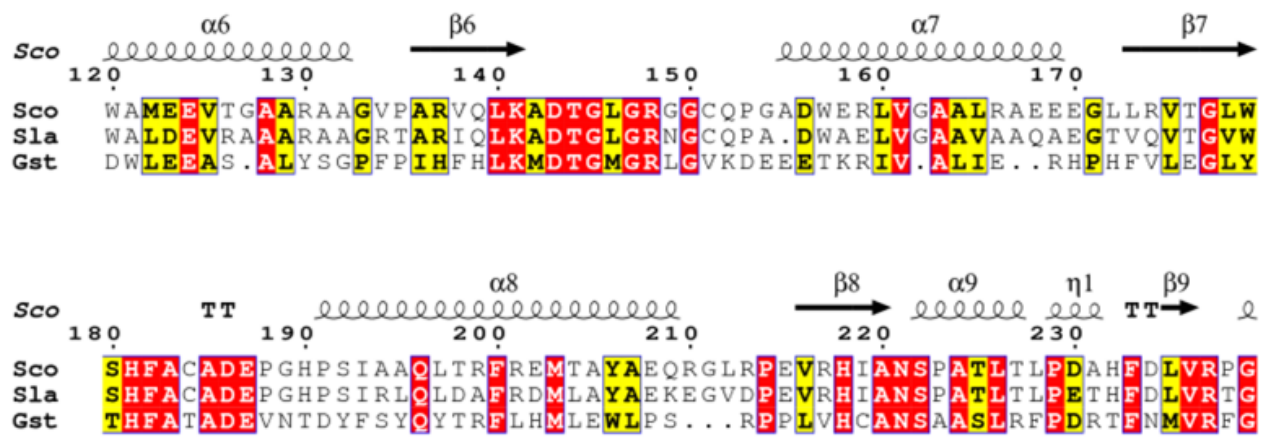

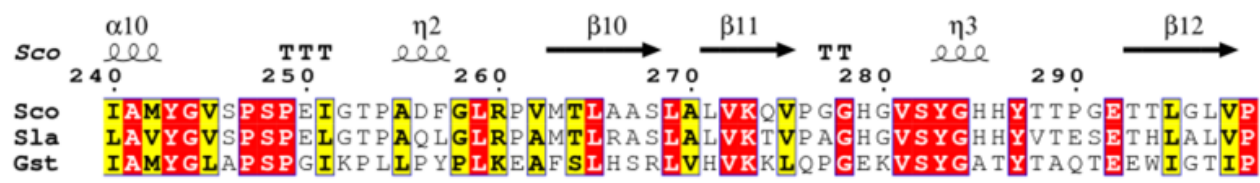

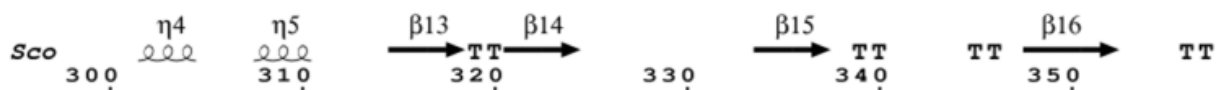

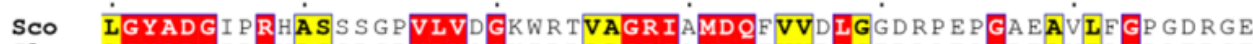

Sla AGYADGIPRNASGRGPVLVAGKIRRAAGRIAMDQFVVDLGEDLAEAGDEAVILGDAERGE

Gst IGYADGWLRRLQ. HF HVLVDGQKAPIVGRICMDQCMIRLPGPLP. VGTKVTIIGRQGDEV

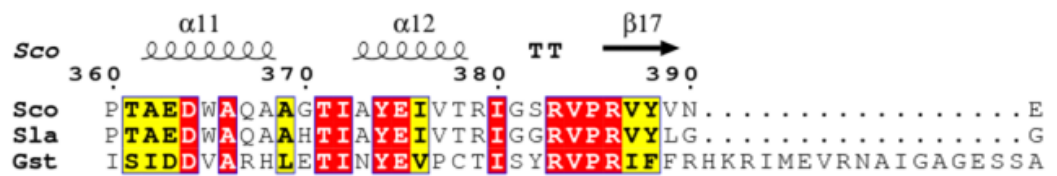


Figure 3
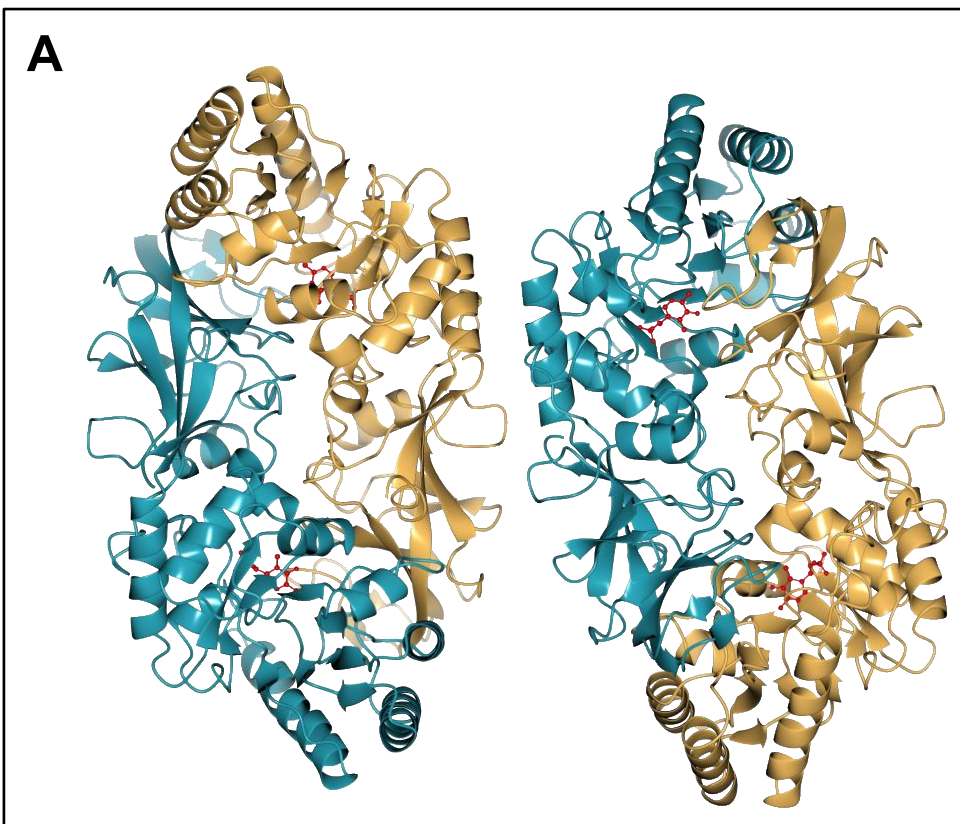

B

$\square$ Alpha-helixes

$\square$ Beta-strands

$\square$ Loop regions

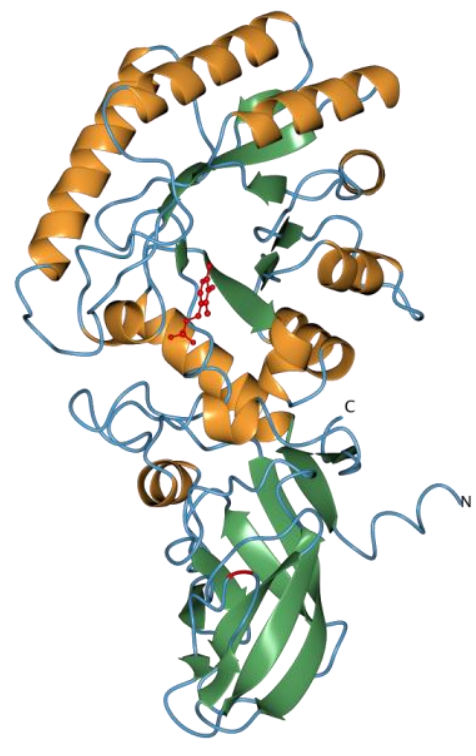


Figure 4

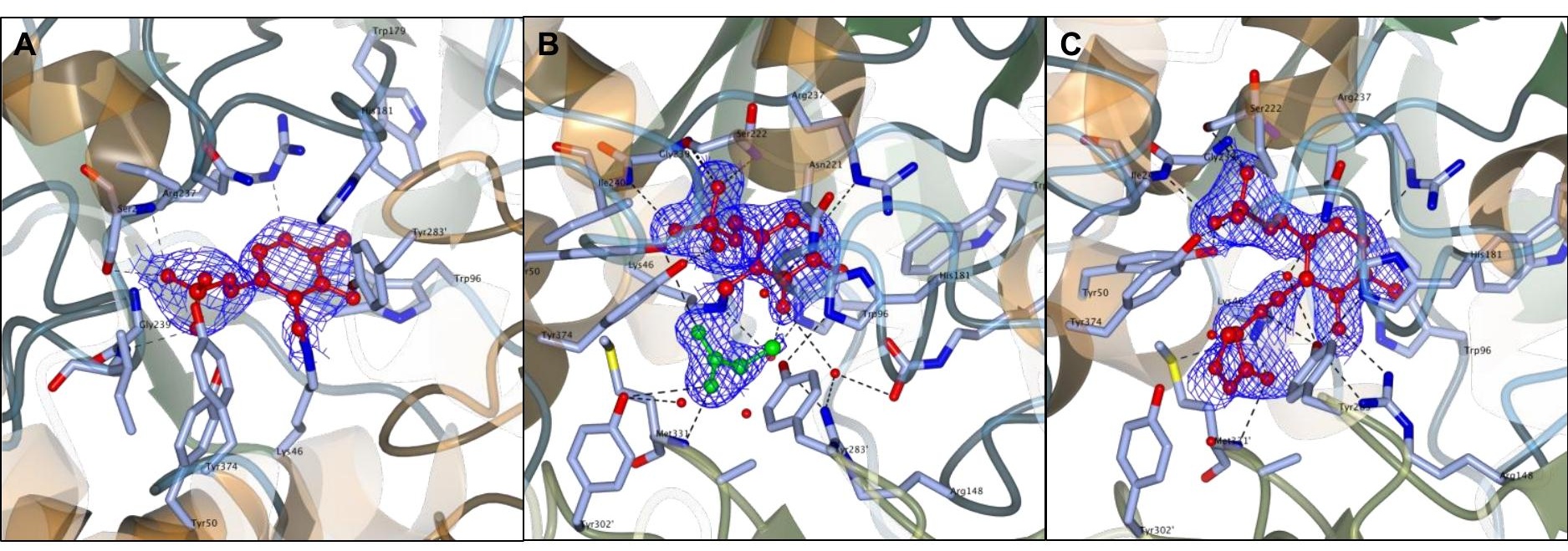

